\title{
Low levels of CD72 and CD100 expression on circulating lymphocytes in immunosuppressive phase of sepsis is associated with mortality in septic patients
}

Yang Yang, Jiajun Chen, Manli Tang, Chengla Yi, Wei Gao, Xiangjun Bai*, Zhanfei Li and Fan Yang ${ }^{*}$ (1)

\begin{abstract}
Background: Despite improvements in antimicrobial therapy and supportive care, sepsis is still a major public health issue. Recently, CD100 and its receptor in the immune system CD72 were shown to play a major role in immune regulation. The purpose of this study was to investigate the expression and clinical correlations of CD72 and CD100 on circulating lymphocytes of septic patients.
\end{abstract}

Methods: In total, 24 healthy controls and 54 septic patients were enrolled in this study. Considering the focus of the current study was on the immunosuppressive phase of sepsis, blood samples of patients were collected at days 3-4 after the onset of sepsis. The levels of CD72 and CD100 expression on circulating lymphocytes were measured by flow cytometry and serum IL-6, IL-10, and immunoglobulin M levels were determined by enzyme-linked immunosorbent assay.

Results: Our results showed that the levels of CD100 expression on T cells and CD72 expression on B cells were significantly lower in septic patients. Similarly, a significant decrease in the expression levels of CD72 and CD100 was observed in non-survivors compared with survivors. In addition, the reduction of immunoglobulin M levels and lymphocyte counts were correlated with the low CD72 and CD100 expression levels. Multivariate logistic regression analysis showed that the percentage of $\mathrm{CD} 100^{+} / \mathrm{CD} 8^{+} \mathrm{T}$ cells and $\mathrm{CD}_{2}{ }^{+} / \mathrm{CD} 19^{+} \mathrm{B}$ cells were independent predictors of 28 -day mortality in septic patients. Simultaneously, the receiver operating characteristic curve analysis showed that the combination of the percentage of $\mathrm{CD}_{100^{+}} / \mathrm{CD}^{+} \mathrm{T}$ cells and sequential organ failure assessment score had the best predictive value of mortality risk.

Conclusions: Our study demonstrated that the decrease of the levels of CD72 and CD100 expression on circulating lymphocytes after 3-4 days of sepsis had a close correlation of the 28-day mortality of septic patients. Thus, CD72 and CD100 are promising biomarkers for assessing the prognosis of patients with sepsis.

(Continued on next page)

\footnotetext{
*Correspondence: BxjTJtrauma@126.com; yfTJtrauma@126.com Yang Yang is the first author.

Trauma Center/Department of Emergency and Traumatic Surgery, Tongji Hospital of Tongji Medicine College, Huazhong University of Science and Technology, 1095 Jiefang Road, Wuhan 430030, China
}

(C) The Author(s). 2020 Open Access This article is licensed under a Creative Commons Attribution 4.0 International License, which permits use, sharing, adaptation, distribution and reproduction in any medium or format, as long as you give appropriate credit to the original author(s) and the source, provide a link to the Creative Commons licence, and indicate if changes were made. The images or other third party material in this article are included in the article's Creative Commons licence, unless indicated otherwise in a credit line to the material. If material is not included in the article's Creative Commons licence and your intended use is not permitted by statutory regulation or exceeds the permitted use, you will need to obtain permission directly from the copyright holder. To view a copy of this licence, visit http://creativecommons.org/licenses/by/4.0/. The Creative Commons Public Domain Dedication waiver (http://creativecommons.org/publicdomain/zero/1.0/) applies to the data made available in this article, unless otherwise stated in a credit line to the data. 
(Continued from previous page)

Trial registration: Peripheral blood lymphocytes analysis detects CD72 and CD100 alteration in trauma patients; ChiCTR1900026367; Registered 4 October 2019; http://www.chictr.org.cn.

Keywords: Sepsis, Lymphocyte, CD72, CD100, Mortality, Immunosuppressive

\section{Background}

Sepsis is defined as life-threatening organ dysfunction caused by a dysregulated host response to infection [1]. Despite improvements in antimicrobial therapy and supportive care, sepsis is still a major public health issue. To date, existing epidemiologic studies suggest that global estimates of 31.5 million sepsis and 19.4 million severe sepsis cases, with potentially 5.3 million deaths annually [2]. In sepsis, the immune response that is initiated by an invading pathogen fails to return to homeostasis, thus culminating in a pathological syndrome that is characterized by sustained excessive inflammation and immune suppression [3]. Moreover, a number of studies have demonstrated that severe immunosuppression was the key cause of high mortality [4]. Therefore, knowledge of the complex immunopathological mechanisms of sepsisinduced immunosuppression is essential for precision medicine in sepsis.

CD100 (also called SEMA4D) is a $150-\mathrm{kDa}$ protein that belongs to the class IV of the semaphorin family [5]. Generally, CD100 is expressed abundantly on the surface of $\mathrm{T}$ cells and weakly on dendritic cells (DCs), B cells, and NK cells [5-8]. Both in human and mice it was demonstrated that CD100 influenced T-cell activation, DCs activation and migration, B-cell survival, NK-cell killing activity [5-8]. CD100 functions as a ligand and binds to three different receptors: the low-affinity receptor CD72, in lymphoid tissue, and the high-affinity receptors plexin $\mathrm{B} 1$ and plexin $\mathrm{B} 2$, in nonlymphoid tissue [9-11]. CD72 (originally Lyb-2) is a $45-\mathrm{kDa}$ type II transmembrane glycoprotein that belongs to the calcium-dependent C-type lectin family [12, 13]. CD72 is expressed primarily on B cells and weakly on $\mathrm{T}$ cells, and it is known as a negative regulator of B cells [14]. Furthermore, previous studies have highlighted that the interaction of CD100 and CD72 is essential for maintaining immunological homeostasis $[15,16]$.

Although CD100 and CD72 have attracted particular attention due to their extensive functions in the immune system, research has mainly focused on the roles of CD72 and CD100 in viral infections and autoimmune diseases [17-19], little research has explored the relationship between CD72/CD100-related molecules and the progress of sepsis, and evaluated which CD72/ CD100-related molecules are reliable biomarkers to predict mortality in the immunosuppressive phase of sepsis. Therefore, we designed this study to investigate whether CD72 and CD100 expression on circulating lymphocytes during the immunosuppressive phase of septic patients can be used to evaluate the prognosis of septic patients. Furthermore, we evaluated the prognostic value of the combination of the best CD72/CD100-related predictors and conventional clinical risk parameters in septic patients.

\section{Materials and methods}

\section{Patients and controls}

Fifty-four septic patients (included twenty-two septic shock patients) were enrolled on admission to the Department of Emergency and Traumatic Surgery of Tongji Hospital of Tongji Medical College of Huazhong University of Science and Technology at days 1-2 after sepsis was diagnosed. According to the Sepsis-3 [1], sepsis was defined as life-threatening organ dysfunction caused by a dysregulated host response to infection. And organ dysfunction was identified as an acute change in total sequential organ failure assessment (SOFA) score $\geq 2$ points consequent to the infection. Moreover, patients with septic shock can be identified with a clinical construct of sepsis with persisting hypotension requiring vasopressors to maintain mean arterial pressure (MAP) $\geq 65 \mathrm{mmHg} 65$ $\mathrm{mmHg}$ and having a serum lactate level $>2 \mathrm{mmol} / \mathrm{L}(18$ $\mathrm{mg} / \mathrm{dL}$ ) despite adequate volume resuscitation. Besides, patients who met the following criteria were excluded: (a) age less than 18 years; (b) patients with pregnancy; (c) sepsis occurred more than 3 days prior to admission; (d) patients who died within 2 days after the onset of sepsis; (e) use of immunosuppressive medication in the past 8 weeks; (f) patients with malignancy, autoimmune diseases or chronic viral infections (hepatitis, HIV). In this study, blood samples of septic patients were collected at days 34 after the onset of sepsis due to the investigation's focus on the immunosuppressive phase of sepsis $[20,21]$. In addition, twenty-four age- and sex-matched healthy adult volunteers without medical problems were recruited as healthy controls. This protocol was approved by the medical ethics committee of Tongji Hospital affiliated to Tongji Medical College of Huazhong University of Science and Technology, and informed consent was obtained from all participants according to the Declaration of Helsinki.

\section{Data collection}

The clinical data, including age, gender, the counts of white blood cell (WBC), the counts of lymphocyte (LC), the levels of C-reaction protein (CRP), site of infection, 
microbial data, SOFA score, simplified acute physiology score II (SAPS II) and acute physiology and chronic health evaluation II (APACHE II) score were recorded at days 3-4 after the onset of sepsis. In addition, the mortality during the 28-day study period was also recorded.

\section{Flow cytometry}

Blood samples of septic patients were collected in EDTA vacutainer and transported to the laboratory at $4{ }^{\circ} \mathrm{C}$ within $2 \mathrm{~h}$. Erythrocytes were lysed using Lysing Buffer (BD Bioscience) and cells were stained with fluorescenceconjugated antibodies (CD3, CD4, CD8, CD19, CD72, CD100 by BD Bioscience). According to the manufacturer's recommendations antibodies were used: BV510labeled anti-CD3 (5 $\mu \mathrm{l}$, clone HIT3a), BB700-labeled antiCD4 (5 $\mathrm{ll}$, clone SK3), PECy7-labeled anti-CD8 (5 $\mu \mathrm{l}$, clone RPA-T8), PE-labeled anti-CD19 $(20 \mu \mathrm{l}$, clone HIB19), FITC-labeled anti-CD72 (20 $\mu$ l, clone J4-117), and Alexa647-labeled anti-CD100 (5 $\mu$, clone A8) per $100 \mu \mathrm{l}$ of whole blood. After 30 min of light-protected incubation, the cells were washed, centrifuged, and subjected to flow-cytometric analysis. Samples were run on a CytoFlex Flow cytometer (Beckman Coulter, Inc.) and analyzed using CytoFlex Software version 2.0 (Beckman Coulter, Inc.). Lymphocytes were gated by side scatter (SSC) and forward scatter (FSC). T cells were defined as $\mathrm{CD}^{+}$(subsequent analysis for $\mathrm{CD} 4^{+}$and $\mathrm{CD} 8^{+}$), $\mathrm{B}$ cells were defined as $\mathrm{CD} 19^{+}$(Fig. 1). Results were expressed as percentages.

\section{Cytokine and immunoglobulin $M$ measurement}

Serum levels of interleukin-6 (IL-6) and IL-10 were determined using commercially available human ELISA kits (ELK Biotechnology Co., Ltd, Wuhan, China) according to the manufacturer's instructions. In addition, serum levels of immunoglobulin $\mathrm{M}$ (IgM) were tested by human IgM ELISA kit (BD Biosciences).

\section{Statistical analysis}

Considering that the skewed distribution of most parameters, data were expressed as median (interquartile ranges), frequencies and percentages unless otherwise indicated. Comparisons between groups were performed using Pearson $\chi^{2}$ test or Fisher exact test for categorical variables, as appropriate. For continuous data, the Shapiro-Wilk test was used for testing normality. Normally distributed data were compared using Student's $t$ test or ANOVA for two or more than two groups, respectively. Mann-Whitney $U$ test or Kruskal-Wallis test was employed for data of non-normal distribution. To determine the discriminative power of CD72 and CD100 expression levels in septic patients for 28-day mortality, the receiver operating characteristic (ROC) curves were constructed, and the significance of the differences between AUCs was estimated by using DeLong test.
Spearman's rank correlation coefficient was used to test correlations between different parameters. For septic survival studies, Kaplan-Meier analyses were performed, and log-rank test was applied for the comparisons of survival distributions. To identify which CD100/CD72 related molecules were independently associated with 28-day mortality in septic patients, univariate and multivariate logistic regression analysis were performed. Statistical analyses and graphics were done using SPSS 23.0 (IBM Crop., Armonk, NY, USA), GraphPad Prism 8.02 (GraphPad Software, Inc., La Jolla, CA, USA) and MedCalc 12.7 (Ostend, Belgium). All statistical tests were two-tailed, and $P<0.05$ were considered statistically significant.

\section{Results}

Patient characteristics

The demographic and clinical characteristics of the patients and healthy controls are shown in Tables 1, 2, and S1. In the patient group, higher SOFA score, APACHE II score and SAPS II indicated a high level of severity. Meanwhile, the comparison of survivors and nonsurvivors also showed significant differences in SOFA score, APACHE II score, and SAPS II. Moreover, the major site of infection was thorax and the major cause of sepsis was bacterial infection (gram-positive).

\section{The expression levels of CD72 and CD100 were both decreased in septic patients}

The expression of CD72 and CD100 were measured on circulating $\mathrm{CD}^{+} \mathrm{T}$ cells, $\mathrm{CD} 8^{+} \mathrm{T}$ cells, and $\mathrm{CD} 19^{+} \mathrm{B}$ cells at days 3-4 after the onset of sepsis (Fig. 2). In this study, the levels of CD72 expression on $\mathrm{T}$ cells and CD100 expression on B cells were very low both in healthy controls and patients (data not shown), so the comparisons between them were not performed. Comparison with healthy controls, the percentages of circulating $\mathrm{CD} 100^{+} / \mathrm{CD}^{+} \mathrm{T}$ cells, $\mathrm{CD} 100^{+} / \mathrm{CD}^{+} \mathrm{T}$ cells, and $\mathrm{CD} 72^{+} / \mathrm{CD} 19^{+} \mathrm{B}$ cells were significantly lower in septic patients (Table 1 and Fig. 2). Moreover, they were also obviously different between septic patients and septic shock patients (Table 1). Meanwhile, in non-survivors, the percentages of $\mathrm{CD} 100^{+} / \mathrm{CD}^{+} \mathrm{T}$ cells, $\mathrm{CD} 100^{+} / \mathrm{CD}^{+}$ $\mathrm{T}$ cells, and $\mathrm{CD} 72^{+} / \mathrm{CD} 19^{+} \mathrm{B}$ cells were remarkably lower in comparison with survivors (Table 2 and Fig. 2).

\section{The alteration of serum cytokine and IgM levels were related to the expression levels of CD72 and CD100}

High levels of pro- and anti-inflammatory cytokines were common in septic patients. In this study, we showed serum IL-6 and IL-10 levels were significantly elevated in septic patients (Table 1). However, only serum IL-6 levels were dramatically increased in septic shock patients compared to septic patients (Table 1). Similar results were also 

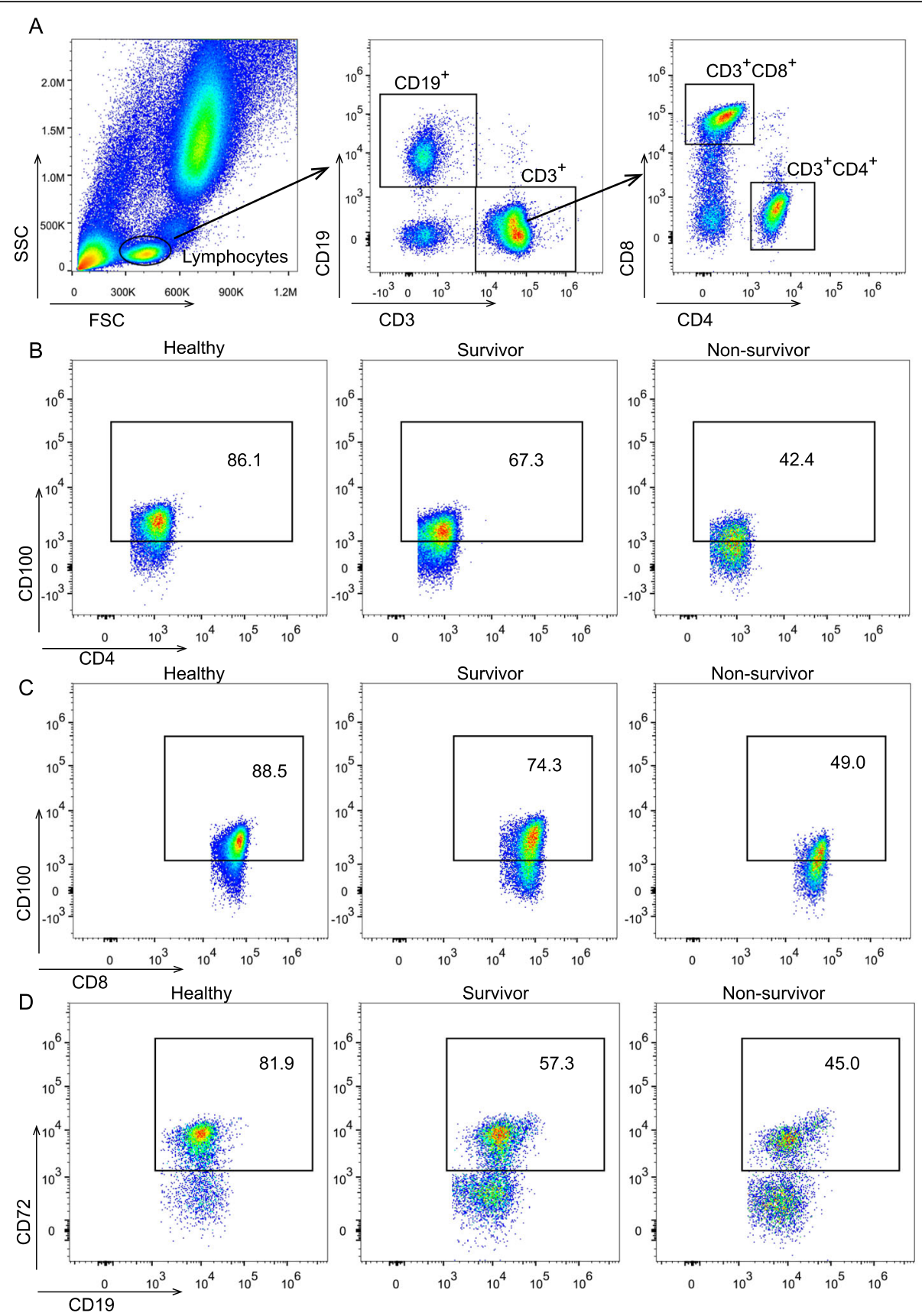

Fig. 1 Representative flow pseudo-color of lymphocytes gating strategy (a) and the levels of CD100 expression on CD4 ${ }^{+} T$ cells (b), CD100 expression on CD8 ${ }^{+}$ T cells (c), CD72 expression on CD19+ B cells $(\mathbf{d})$, in healthy controls $(n=24)$, septic survivors $(n=38)$, and septic non-survivors $(n=16)$, respectively

observed when compared non-survivors with survivors (Table 2). Additionally, serum IL-6 levels were reversely correlated with the percentages of $\mathrm{CD} 100^{+} / \mathrm{CD} 4^{+} \mathrm{T}$ cells and the percentages of $\mathrm{CD}_{100^{+}} / \mathrm{CD}^{+} \mathrm{T}$ cells $(r=-0.3541$ and -0.3124 , respectively) (Fig. $3 \mathrm{~b}$ and $\mathrm{f}$ ). On the other hand, serum IgM levels dropped in turn in healthy controls, survivors, and non-survivors (Tables 1, 2). Meanwhile, significant positive correlations were observed between serum IgM levels and the percentages of
$\mathrm{CD} 100^{+} / \mathrm{CD}^{+}{ }^{+} \mathrm{T}$ cells, $\mathrm{CD} 100^{+} / \mathrm{CD}^{+} \mathrm{T}$ cells, and $\mathrm{CD}^{+} 2^{+} /$ CD $19^{+}$B cells $(r=0.3031,0.5168$, and 0.324 , respectively) (Fig. 3d, h, and l).

\section{Lymphopenia was correlated with the low expression levels of CD72 and CD100}

Lymphopenia was ubiquitous in septic patients (Table 1 ), including $\mathrm{CD} 4^{+} \mathrm{T}$ cells, $\mathrm{CD} 8^{+} \mathrm{T}$ cells and $\mathrm{CD} 19^{+} \mathrm{B}$ cells (Table S2), and more significant reduction was 
Table 1 Baseline characteristics of healthy controls and patients

\begin{tabular}{|c|c|c|c|c|}
\hline Parameters & Healthy & Sepsis & Septic shock & $P$ \\
\hline Number & 24 & 32 & 22 & NA \\
\hline Age (years) & $47(44-52)$ & $51(47-58)$ & $47(42-53)^{b}$ & 0.0474 \\
\hline Male, n (\%) & $17(70.8 \%)$ & 27 (84.4\%) & $16(72.7 \%)^{b}$ & 0.423 \\
\hline WBC $(10 \wedge 9 / L)$ & $7.58(7.34-7.88)$ & $14.22(12.68-16.57)$ & $14.30(13.22-15.77)^{b}$ & $<0.0001$ \\
\hline LC (10^9/L) & $2.05(1.90-2.15)$ & $0.91(0.77-1.09)$ & $0.77(0.68-0.92)^{a}$ & $<0.0001$ \\
\hline SOFA score & NA & $7(5-10)$ & $9(7-11)^{a}$ & 0.047 \\
\hline SAPS ॥ & NA & $29(23-34)$ & $36(26-46)^{a}$ & 0.0311 \\
\hline APACHE II score & NA & $14(12-17)$ & $17(15-21)^{a}$ & 0.008 \\
\hline CRP (mg/L) & $1.3(0.8-1.8)$ & $126.7(104.2-146.5)$ & $131.9(107.8-168.7)^{b}$ & $<0.0001$ \\
\hline $\lg M(g / L)$ & $1.78(1.48-2.15)$ & $0.84(0.76-1.0)$ & $0.83(0.72-0.93)^{b}$ & $<0.0001$ \\
\hline IL-6 (pg/ml) & $10.6(9.65-11.6)$ & $80.0(64.81-91.54)$ & $88.58(78.58-95.49)^{a}$ & $<0.0001$ \\
\hline IL-10 (pg/ml) & $10.09(9.14-11.17)$ & $87.6(75.88-100.9)$ & $88.43(72.94-98.84)^{\mathrm{b}}$ & $<0.0001$ \\
\hline $\mathrm{CD}_{100^{+}} / \mathrm{CD}^{+} \mathrm{T}$ cells $\%$ & $80.9(74.3-83.2)$ & $67.0(58.7-73.3)$ & $52.8(48.3-63.2)^{\mathrm{a}}$ & $<0.0001$ \\
\hline $\mathrm{CD} 100^{+} / \mathrm{CD}^{+} \mathrm{T}$ cells $\%$ & $81.2(76.2-85.5)$ & $71.5(62.7-77.4)$ & $59.8(48.0-75.4)^{a}$ & $<0.0001$ \\
\hline $\mathrm{CD}^{2} 2^{+} / \mathrm{CD} 19^{+} \mathrm{B}$ cells $\%$ & $72.8(69.9-79.3)$ & $67.9(59.8-73.9)$ & $58.5(48.3-72.4)^{a}$ & $<0.0001$ \\
\hline 28-day mortality, n (\%) & NA & $7(21.9 \%)$ & $9(40.9 \%)^{b}$ & 0.132 \\
\hline
\end{tabular}

Data are shown as median (interquartile ranges), frequencies and percentages. ANOVA and Kruskal-Wallis tests were performed for multi-group comparisons. a Denotes $P<.05$ and ${ }^{b}$ denotes $P>.05$ comparing sepsis group and septic shock group. NA Not applicable, WBC Counts of white blood cell, $L C$ Counts of lymphocyte, SOFA Sequential organ failure assessment, SAPS II Simplified acute physiology score II, APACHE II Acute physiology and chronic health evaluation II, IgM Immunoglobulin M, CRP C-reaction protein, IL Interleukin

Table 2 Baseline characteristics of septic survivors and non-survivors

\begin{tabular}{|c|c|c|c|c|}
\hline Parameters & Survivor & Non-survivor & Overall population & $P$ \\
\hline Number & 38 & 16 & 54 & NA \\
\hline Age (years) & $49(45-56)$ & $50(45-61)$ & $49(45-56)$ & 0.458 \\
\hline Male, $n(\%)$ & 31 (81.6\%) & $12(75 \%)$ & $43(79.6 \%)$ & 0.714 \\
\hline WBC (10^9/L) & $14.22(12.43-15.77)$ & $14.85(13.68-17.45)$ & $14.23(13.09-16.44)$ & 0.0709 \\
\hline LC (10^9/L) & $0.89(0.75-1.05)$ & $0.77(0.66-0.90)$ & $0.86(0.71-1.03)$ & 0.0316 \\
\hline SOFA score & $7(6-9)$ & $10(9-13)$ & $8(6-10)$ & $<0.0001$ \\
\hline SAPS ॥ & $28(24-34)$ & $43(31-50)$ & $31(25-42)$ & 0.0011 \\
\hline APACHE II score & $14(12-16)$ & $19(16-22)$ & $15(13-19)$ & 0.0005 \\
\hline CRP (mg/L) & $124.5(101.1-148.3)$ & $137.3(117.4-175.2)$ & $126.9(105.7-157.1)$ & 0.076 \\
\hline $\lg M(g / L)$ & $0.85(0.78-1.01)$ & $0.73(0.63-0.91)$ & $0.84(0.75-0.95)$ & 0.0067 \\
\hline IL-6 (pg/ml) & $80(68-91.08)$ & $93.01(81.01-100.9)$ & $83.13(72.8-94.26)$ & 0.0114 \\
\hline IL-10 (pg/ml) & $83.72(70.76-97.9)$ & $94.44(80.86-104.4)$ & $87.6(75.33-100.6)$ & 0.1093 \\
\hline $\mathrm{CD}_{100^{+}} / \mathrm{CD}^{+} \mathrm{T}$ cells $\%$ & $66.4(54.9-75.6)$ & $53.9(46.4-65.5)$ & $61.8(50.1-71.5)$ & 0.0174 \\
\hline $\mathrm{CD}_{100^{+}} / \mathrm{CD}^{+} \mathrm{T}$ cells $\%$ & $73.3(63.1-77.9)$ & $54.4(48.9-69)$ & $70.8(56.2-76.3)$ & 0.0003 \\
\hline $\mathrm{CD}_{2} 2^{+} / \mathrm{CD} 19^{+} \mathrm{B}$ cells $\%$ & $68.4(59.1-74.5)$ & $54.9(46-66.4)$ & $65.8(55.6-73.2)$ & 0.0018 \\
\hline
\end{tabular}

Data are shown as median (interquartile ranges), frequencies and percentages. The comparisons just performed between survivors and non-survivors, using Student's $t$ test or Mann-Whitney U test. NA Not applicable, WBC Counts of white blood cell, LC Counts of lymphocyte, SOFA Sequential organ failure assessment, APACHE II Acute physiology and chronic health evaluation II, SAPS I/ Simplified acute physiology score II, CRP C-reaction protein, IgM Immunoglobulin M, $I L$ interleukin 


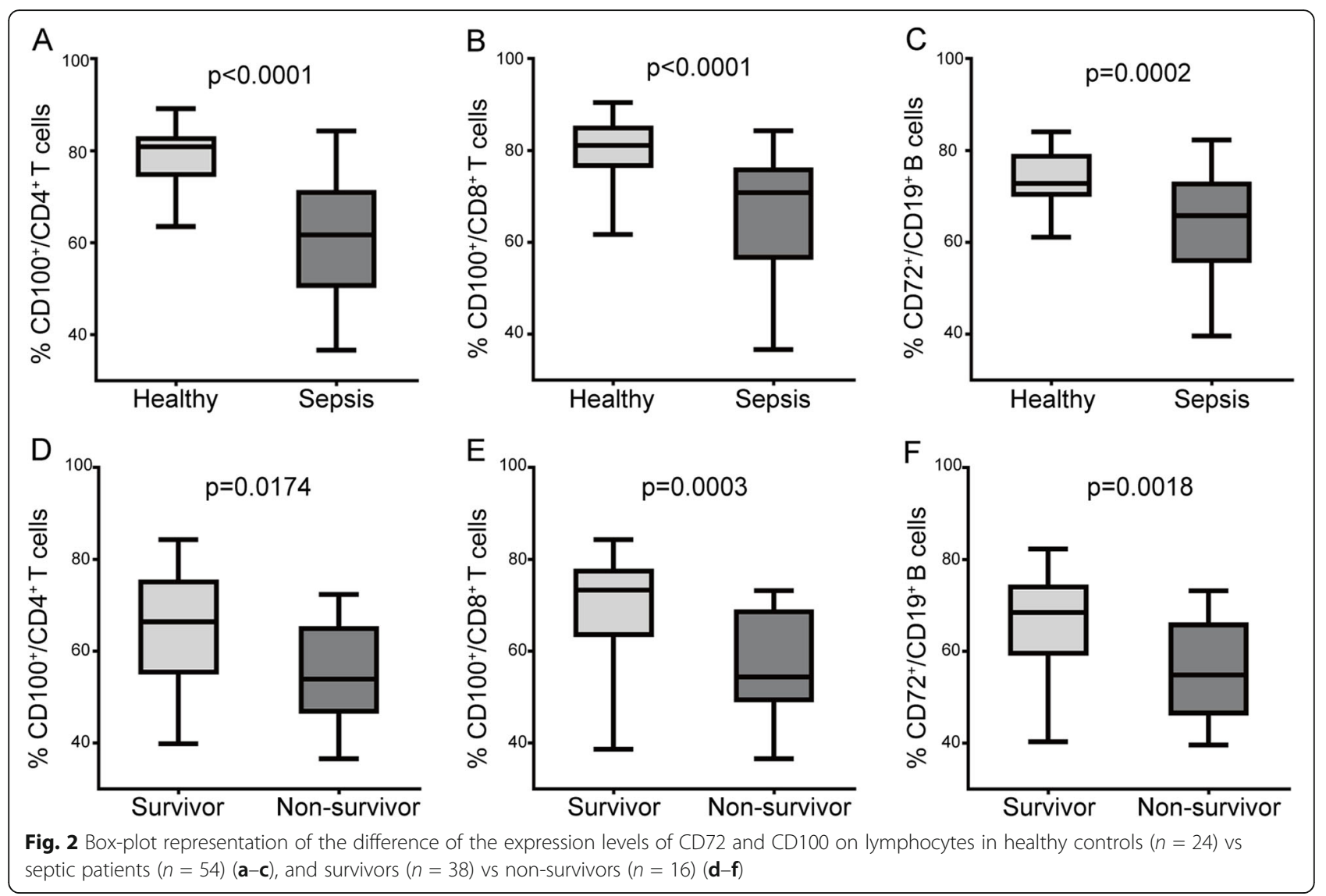

observed when compared septic non-survivors with survivors (Table 2). Furthermore, we found that lymphocyte counts were positively correlated with the percentages of $\mathrm{CD} 100^{+} / \mathrm{CD}^{+} \mathrm{T}$ cells, $\mathrm{CD} 100^{+} / \mathrm{CD}^{+} \mathrm{T}$ cells, and $\mathrm{CD}_{2} 2^{+} / \mathrm{CD} 19^{+} \mathrm{B}$ cells $(r=0.5106,0.2705$, and 0.3051, respectively) (Fig. 3a, e, and i).

\section{Predictive value of CD72/CD100-related molecules for mortality in septic patients}

The ROC curves of CD72/CD100-related molecules for predicting 28-day mortality are shown in Fig. 4 . The ROC curve analysis (area under the curve (AUC)) showed that the percentage of $\mathrm{CD} 100^{+} / \mathrm{CD}^{+} \mathrm{T}$ cells, $\mathrm{CD} 100^{+} / \mathrm{CD}^{+}{ }^{+} \mathrm{T}$ cells, $\mathrm{CD} 72^{+} / \mathrm{CD} 19^{+} \mathrm{B}$ cells for predicting 28-day mortality were $0.695,0.803$, and 0.765 , respectively (Table S3). It was clear that the levels of CD100 expression on $\mathrm{CD}^{+} \mathrm{T}$ cells had a better predictive value than the others.

Subsequently, we explored the prognostic significance of the combination of the best CD72- and CD100related predictors (namely the levels of CD100 expression on $\mathrm{CD}^{+} \mathrm{T}$ cells) with conventional clinical risk parameters (SOFA score, APACHE II score, and SAPS II). The results displayed the combination of the percentage of $\mathrm{CD} 100^{+} / \mathrm{CD}^{+} \mathrm{T}$ cells and SOFA score had the largest AUC (Table S3). We estimated the difference of ROC between the single parameter and combined parameter by using DeLong test (Table S4). Our results showed that there were no statistical differences between the single parameter and combined parameter, though the combined parameter had larger AUCs than a single parameter.

Furthermore, by using cutoff values determined by ROC, we observed septic patients with the percentage of $\mathrm{CD} 100^{+} / \mathrm{CD} 4^{+} \mathrm{T}$ cells, $\mathrm{CD} 100^{+} / \mathrm{CD}^{+} \mathrm{T}$ cells, $\mathrm{CD} 72^{+} /$ $\mathrm{CD} 9^{+} \mathrm{B}$ cells lower than $54.9 \%$ (sensitivity was $76.3 \%$ and specificity was $56.3 \%$ ), $62.9 \%$ (sensitivity was $78.9 \%$ and specificity was $75 \%$ ), and $59.0 \%$ (sensitivity was $76.3 \%$ and specificity was $68.8 \%$ ), respectively, had a lower probability of survival at day 28 after the onset of sepsis (Fig. 5). Univariate and multivariate logistic regression analysis were conducted to predict the 28-day mortality of patients with sepsis. At first, we conducted the univariate logistic regression analysis. Statistically significant variables in univariate analysis were conserved in the multivariate logistic model. Subsequently, the percentage of $\mathrm{CD}_{100^{+}} / \mathrm{CD}^{+} \mathrm{T}$ cells $(B=-0.095$, OR $=0.909, P=0.004)$ and the percentage of $\mathrm{CD}^{2} 2^{+} / \mathrm{CD} 19^{+}$ 


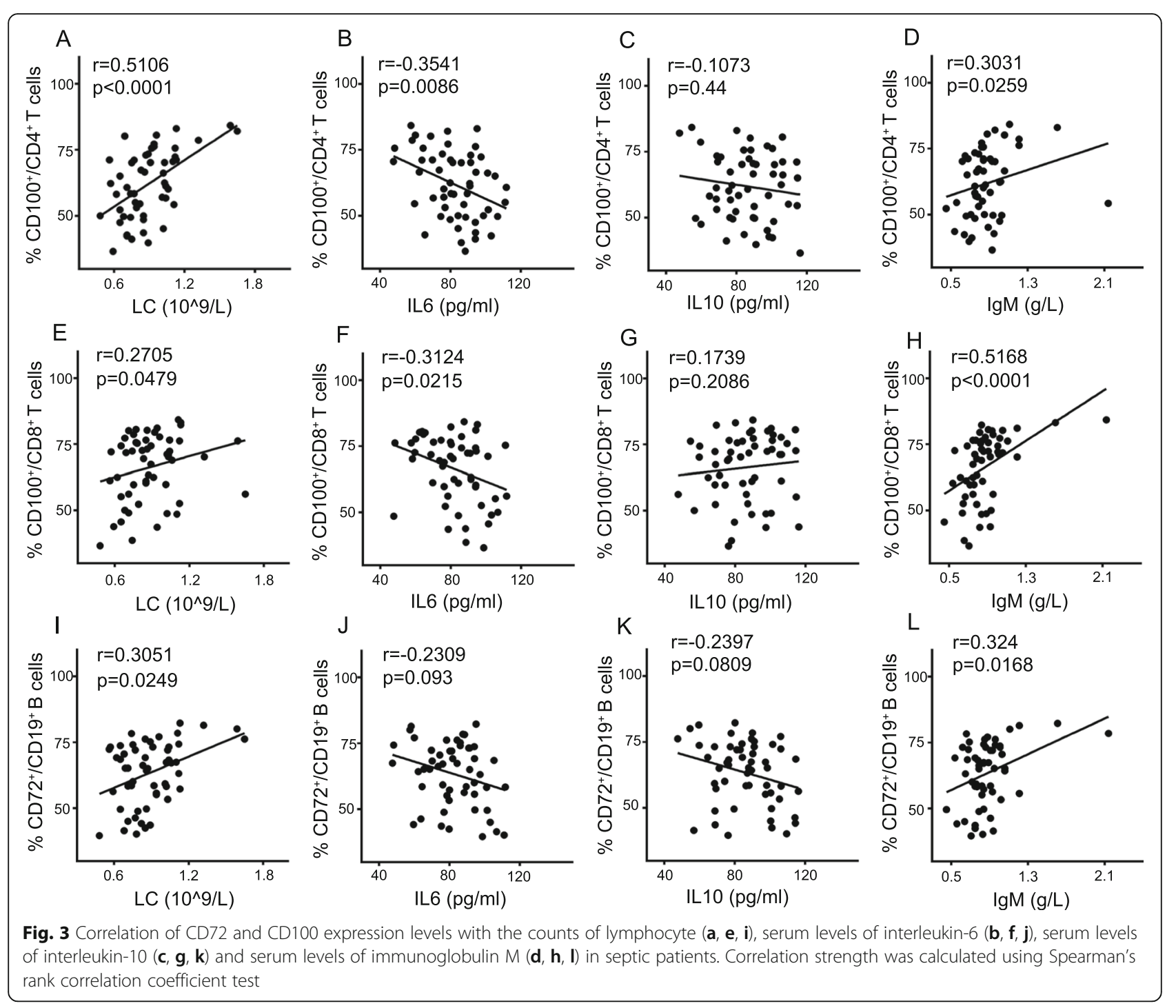

B cells $(B=-0.086, \mathrm{OR}=0.918, P=0.012)$ were found to be independent predictors of 28-day mortality in septic patients. The details were presented in Table 3.

\section{Discussion}

Sepsis is an important medical problem of the 21st century that warrant renewed attention. In China, the incidence of severe sepsis was estimated to be more than 100 cases per 100,000 people, and the hospital mortality of sepsis was nearly $20.6 \%$ [22]. The high mortality rates of sepsis are partially due to the lack of an effective approach to predict the prognosis of sepsis. Thus, identifying novel efficient biomarkers for a better management of sepsis is urgent. The current study firstly assessed the levels of CD72 and CD100 expression on circulating lymphocytes at days 3-4 after the onset of sepsis, resulting in three main findings. First, CD72 and CD100 expression levels were both significantly lower in septic patients than in healthy controls. Second, the reduction of lymphocyte counts and serum IgM levels were related to the low expression levels of CD72 and CD100. Third, the percentage of $\mathrm{CD} 100^{+} / \mathrm{CD}^{+} \mathrm{T}$ cells and $\mathrm{CD} 72^{+} /$ $\mathrm{CD} 19^{+} \mathrm{B}$ cells were both independent predictors of 28 day mortality in septic patients.

Lymphopenia is common in sepsis, both in nonsurvivors and survivors, and predicts poor prognosis [23, 24]. To date, numerous studies have revealed that CD100 could regulate the activation and proliferation of $\mathrm{T}$ cells via the interaction with CD72 [15]. Additionally, previous studies have proved that the expression of CD100 on circulating T cells was significantly decreased in HIV patients [25]. Similarly, authors also observed hepatitis $\mathrm{C}$ virus infection reduced CD100 expression on $\mathrm{CD}^{+} \mathrm{T}$ cells [26]. Moreover, accumulated evidence indicated that CD100 could rescue B cells from apoptosis and increase B-cell proliferation and survival [27, 28]. In 

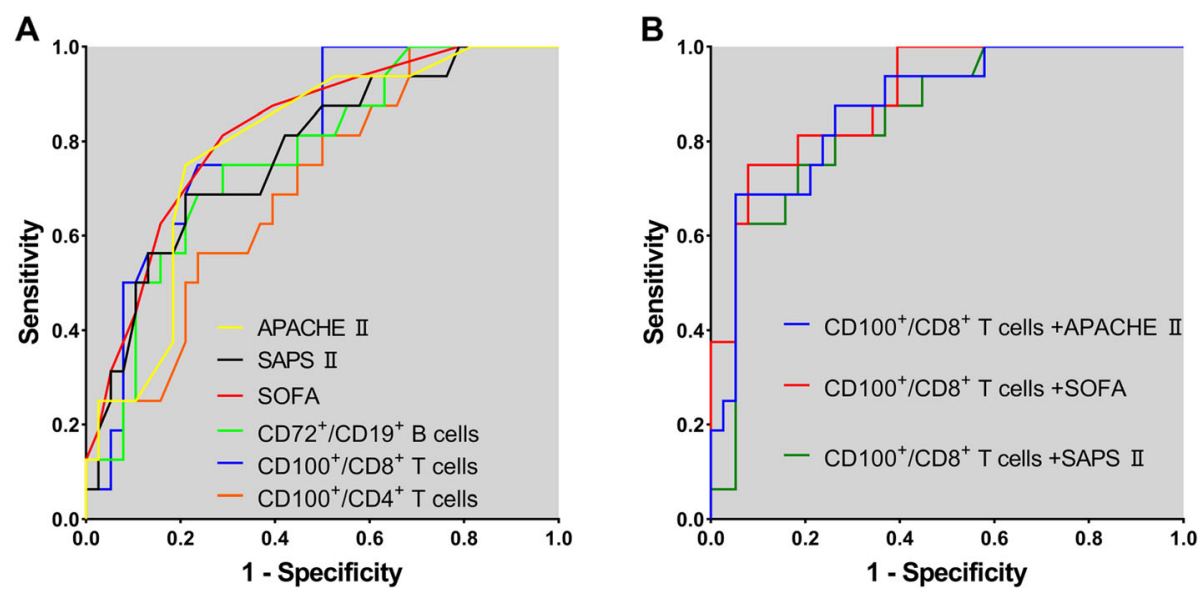

Fig. 4 Receiver operating characteristic (ROC) curves of various indicators in predicting 28-day mortality risk of septic patients. a The AUCs for individual parameter were 0.823 for SOFA score, 0.775 for SAPS $\|, 0.792$ for APACHE $\|$ score, 0.695 for the percentage of CD $100^{+} / \mathrm{CD}^{+}{ }^{+} \mathrm{T}$ cells, 0.803 for the percentage of $\mathrm{CD} 100^{+} / \mathrm{CD}^{+} \mathrm{T}$ cells, 0.765 for the percentage of $\mathrm{CD} 72^{+} / \mathrm{CD} 19^{+} \mathrm{B}$ cells. $\mathbf{b}$ The AUCs for the combination of the percentage of $\mathrm{CD} 100^{+} / \mathrm{CD}^{+}{ }^{+} \mathrm{T}$ cells with SOFA score, SAPS II, or APACHE II score were $0.895,0.846$, and 0.872 , respectively
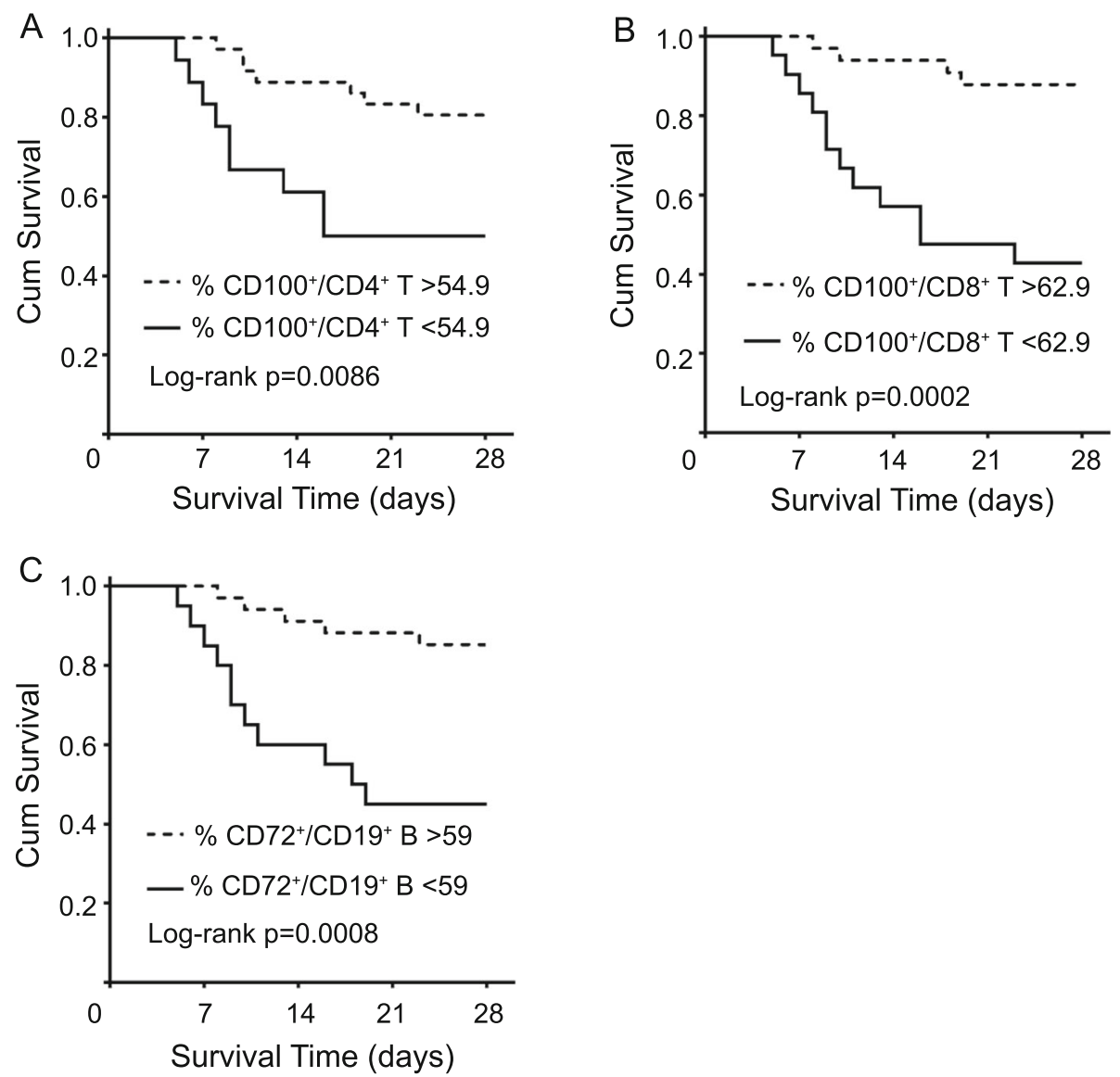

Fig. 5 Survival curves of septic patients according to the percentage of $\mathrm{CD} 100^{+} / \mathrm{CD} 4^{+} T$ cells $(\mathbf{a}), \mathrm{CD} 100^{+} / \mathrm{CD} 8^{+} \mathrm{T}$ cells $(\mathbf{b})$, and $\mathrm{CD} 72^{+} / \mathrm{CD} 19^{+} \mathrm{B}$ cells (c) 
Table $\mathbf{3}$ Logistic regression analysis for prediction of 28-day mortality in sepsis

\begin{tabular}{|c|c|c|c|c|c|c|}
\hline \multirow[t]{2}{*}{ Variable } & \multicolumn{3}{|c|}{ Univariate analysis } & \multicolumn{3}{|c|}{ Multivariate analysis } \\
\hline & $\mathrm{B}$ & OR $(95 \% \mathrm{Cl})$ & $P$ & $\mathrm{~B}$ & OR $(95 \% \mathrm{Cl})$ & $P$ \\
\hline 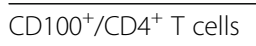 & -0.06 & $0.941(0.894-0.992)$ & 0.023 & & & \\
\hline $\mathrm{CD} 100^{+} / \mathrm{CD}^{+} \mathrm{T}$ cells & -0.095 & $0.91(0.859-0.963)$ & 0.001 & -0.095 & 0.909 (0.853v0.969) & 0.004 \\
\hline $\mathrm{CD}^{+} 2^{+} / \mathrm{CD} 19^{+} \mathrm{B}$ cells & -0.084 & $0.92(0.869-0.974)$ & 0.004 & -0.086 & $0.918(0.858-0.982)$ & 0.012 \\
\hline
\end{tabular}

Statistically significant variables in univariate analysis were conserved in multivariate analysis (Forward, LR, $a=0.05$ ). B: logistic regression coefficient, OR: odds ratio. $\mathrm{Cl}$ : confidence interval

line with the preceding research, our study showed the numbers of circulating lymphocyte were substantially decreased with decreasing CD72 and CD100 expression levels.

Lymphocyte exhaustion was recently recognized as a major mechanism of immune suppression in sepsis, and it was characterized by impaired lymphocyte activation, proliferation, IgM production, and increased susceptibility to secondary infection and poor survival in the immunosuppressive phase of sepsis [29, 30]. Moreover, low serum IgM levels also play a critical role in secondary infection during sepsis, and it is often correlated with increased mortality [30-32]. In this study, we also observed a significant reduction in serum IgM levels in septic patients. More importantly, we found the serum IgM levels were positively correlated with the expression levels of CD72 and CD100, especially the levels of CD100 expression on $\mathrm{CD}^{+} \mathrm{T}$ cells. This can be partly explained by the ligation of CD100 and CD72 could enhance the activation of $\mathrm{B}$ cells in antibody production [7]. Simultaneously, murine studies demonstrated the proliferative responses and immunoglobulin production of B cells were both significantly reduced in CD100deficient mice [33].

Another major characteristic of lymphocyte exhaustion is the increase of expression of various inhibitory receptors, such as cytotoxic $\mathrm{T}$-lymphocyte-associated protein 4 (CTLA-4), B and $\mathrm{T}$ lymphocyte attenuator (BTLA), Programmed cell death receptor-1 (PD-1), and Programmed cell death receptor ligand-1 (PD-L1) [34]. Furthermore, it is currently believed that PD-1 and PD-L1 both play important roles in sepsisinduced immunosuppression [21]. Recently, Correa et al. demonstrated that CD100 expression on $\mathrm{T}$ cells was associated with the expression of PD-1 and PDL1 on $\mathrm{T}$ cells during HIV infection, meanwhile, CD72/CD100 axis was correlated with T-cell exhaustion [17]. Taken together, it is plausible to speculate that CD72 and CD100 may play major roles in the progression of sepsis by regulating lymphocyte exhaustion.

In theory, as an inhibitory receptor that expressed primarily on B cells, the expression levels of CD72 should be increased in varying degrees. However, in the current study, the CD72 expression showed a significant decrease. It may be due to CD72 plays a major role at multiple stages of B-cell development and is necessary for establishing and maintaining the normal peripheral, conventional B-cell pool [14]. According to the development of B cells, B cells are typically classified into pro-B cells, pre-B cells, immature B cells, and mature B cells [35]. Simultaneously, CD72 expression is detectable throughout B-cell differentiation from early progenitors to mature $B$ cells [14]. In adult $\mathrm{CD} 72^{-1-}$ mice, the numbers of pro-B cells, pre-B cells, immature $B$ cells, and mature B cells were normal, significant increase, minimally changed, and significant decrease, respectively [14, 36]. It indicated that the absence of CD72 diminishes the efficiency of the transitions from pre- $\mathrm{B}$ to immature $B$ and from immature to mature B cells. Recently, Duan et al. also released that impaired B-cell maturation contributed to the reduction of B cell numbers, serum IgM levels and poor prognosis in sepsis [37]. Thus, we hypothesize the reduction of CD72 expression on B cells still plays a major role in the development of sepsis. However, more further studies are required in order to explore the alteration of CD72 expression in different stages of B cells.

Some limitations need to be considered in our study. First, the numbers of patients and healthy controls were relatively small, and the data were only collected at a single institution. Second, the expression of CD72/ CD100 was only determined at a single time point, because it was difficult to obtain enough blood samples from all participants. Dynamic monitoring reflects the evolution of CD72/CD100 expression on lymphocytes during sepsis and it may yield predictors with better predictive value; thus, dynamic detection is essential for further study. Third, the number of female patients is too small to rule out the interference caused by gender. Furthermore, the age of septic patients was concentrated between 45 and 56 years; it remains to be explored whether such a conclusion could be generalized to other age groups.

\section{Conclusions}

To conclude, our study revealed that the decrease of the levels of CD72 and CD100 expression on circulating lymphocytes after 3-4 days of sepsis had a close correlation of the 28-day mortality of septic patients, 
substantializing CD72 and CD100 as potential prognostic markers for sepsis.

\section{Supplementary information}

Supplementary information accompanies this paper at https://doi.org/10. 1186/s40560-020-00486-9.

Additional file 1: Table S1. Baseline clinical characteristics of infection in septic patients.

Additional file 2: Table S2. Alterations of different lymphocyte subsets. Additional file 3: Table S3. Area under the curve of various parameters for predicting 28-day mortality in septic patients.

Additional file 4: Table S4. The difference of ROC between the single parameter and combined parameter.

\section{Abbreviations}

WBC: The counts of white blood cell; LC: The counts of lymphocyte; CRP: Creaction protein; SOFA: Sequential organ failure assessment; SAPS II: Simplified acute physiology score II; APACHE I: Acute physiology and chronic health evaluation II; SSC: Side scatter; FSC: Forward scatter; IL: Interleukin; IgM: Immunoglobulin M; ROC: Receiver operating characteristic; AUC: Area under the curve; BTLA: B and T lymphocyte attenuator; CTLA-4: Cytotoxic T-lymphocyte-associated protein 4; PD1: Programmed cell death receptor-1; PD-L1: Programmed cell death receptor ligand-1

\section{Acknowledgements}

The authors are grateful to Bingqing Liu for assisting in statistical analysis. Liu is from the Public Health college of Huazhong University of Science and Technology.

\section{Authors' contributions}

FY is the guarantor of the article, taking responsibility for the integrity of the work as a whole, from inception to published article. XB and ZL supervised the project and provided research funding. JC collected and analyzed data. MT collected data and samples. CY critically revised the manuscript. WG helped data management. YY conceived the idea, performed flow cytometry experiment, drafted and revised the manuscript. All authors read and approved the final manuscript.

\section{Funding}

This research was supported by the National Natural Science Foundation of China (No.81571891 and 81772129).

\section{Availability of data and materials}

Data are available on request.

\section{Ethics approval and consent to participate}

This research was approved by the medical ethics committee of Tongji Hospital affiliated to Tongji Medical College of Huazhong University of Science and Technology, and informed consent was obtained from all participants according to the Declaration of Helsinki.

\section{Consent for publication}

Not applicable.

\section{Competing interests}

The authors declare that they have no conflicts of interest.

Received: 20 July 2020 Accepted: 26 August 2020

Published online: 03 September 2020

\section{References}

1. Singer M, Deutschman CS, Seymour CW, et al. The Third International Consensus Definitions for Sepsis and Septic Shock (Sepsis-3). JAMA. 2016; 315:801-10
2. Fleischmann C, Scherag A, Adhikari NK, et al. Assessment of Global Incidence and Mortality of Hospital-treated Sepsis. Current Estimates and Limitations. Am J Respir Crit Care Med. 2016;193:259-72.

3. van der Poll T, van de Veerdonk FL, Scicluna BP, et al. The immunopathology of sepsis and potential therapeutic targets. Nat Rev Immunol. 2017:17:407-20.

4. Boomer JS, To K, Chang KC, et al. Immunosuppression in patients who die of sepsis and multiple organ failure. JAMA. 2011;306(23):2594-605.

5. Delaire S, Elhabazi A, Bensussan A, et al. CD100 is a leukocyte semaphorin. Cell Mol Life Sci. 1998;54:1265-76.

6. Kumanogoh A, Suzuki K, Ch'ng E, et al. Requirement for the lymphocyte semaphorin, CD100, in the induction of antigen-specific T cells and the maturation of dendritic cells. J Immunol. 2002;169:1175-81.

7. Hall KT, Boumsell L, Schultze JL, et al. Human CD100, a novel leukocyte semaphorin that promotes B-cell aggregation and differentiation. Proc Natl Acad Sci. USA. 1996;93:11780-5.

8. Mizrahi S, Markel G, Porgador A, et al. CD100 on NK cells enhance IFNy secretion and killing of target cells expressing CD72. PLoS One. 2007;2:e818.

9. Kumanogoh A, Watanabe C, Lee I, et al. Identification of CD72 as a lymphocyte receptor for the class IV semaphorin CD100: a novel mechanism for regulating B cell signaling. Immunity. 2000;13:621-31.

10. Tamagnone $L$, Artigiani $S$, Chen $H$, et al. Plexins are a large family of receptors for transmembrane, secreted, and GPI-anchored semaphorins in vertebrates. Cell. 1999;99:71-80.

11. Witherden DA, Watanabe M, Garijo O, et al. The CD100 receptor interacts with its plexin B2 ligand to regulate epidermal $\gamma \delta T$ cell function. Immunity. 2012;37:314-25.

12. Von Hoegen I, Nakayama E, Parnes JR. Identification of a human protein homologous to the mouse Lyb-2 B cell differentiation antigen and sequence of the corresponding cDNA. J Immunol. 1990;144:4870-7.

13. Nakayama E, von Hoegen I, Parnes JR. Sequence of the Lyb-2 B-cell differentiation antigen defines a gene superfamily of receptors with inverted membrane orientation. Proc Natl Acad Sci USA. 1989;86:1352-6.

14. Parnes JR, Pan C. CD72, a negative regulator of B-cell responsiveness. Immunol Rev. 2000;176:75-85.

15. Jiang X, Björkström NK, Melum E. Intact CD100-CD72 Interaction Necessary for TCR-Induced T Cell Proliferation. Front Immunol. 2017;8:765.

16. Kumanogoh A, Shikina T, Watanabe C, et al. Requirement for CD100-CD72 interactions in fine-tuning of B-cell antigen receptor signaling and homeostatic maintenance of the B-cell compartment. Int Immunol. 2005;17: 1277-82.

17. Correa-Rocha R, Lopez-Abente J, Gutierrez C, et al. CD72/CD100 and PD-1/ PD-L1 markers are increased on T and B cells in HIV-1 $1^{+}$viremic individuals, and CD72/CD100 axis is correlated with T-cell exhaustion. PLoS One. 2018; 13:e0203419.

18. Yang S, Wang L, Pan W, et al. MMP2/MMP9-mediated CD100 shedding is crucial for inducing intrahepatic anti-HBV CD8 T cell responses and HBV clearance. J Hepatol. 2019;71:685-98.

19. Vadasz Z, Goldeberg Y, Halasz K, et al. Increased soluble CD72 in systemic lupus erythematosus is in association with disease activity and lupus nephritis. Clin Immunol. 2016;164:114-8.

20. Hotchkiss RS, Monneret G, Payen D. Immunosuppression in sepsis: a novel understanding of the disorder and a new therapeutic approach. Lancet Infect Dis. 2013;13(3):260-8.

21. Shao $R$, Fang $Y, Y u H$, et al. Monocyte programmed death ligand-1 expression after 3-4 days of sepsis is associated with risk stratification and mortality in septic patients: a prospective cohort study. Crit Care. 2016;20:124.

22. Zhou J, Tian H, Du X, et al. Population-Based Epidemiology of Sepsis in a Subdistrict of Beijing. Crit Care Med. 2017:45:1168-76.

23. Venet F, Davin F, Guignant C, et al. Early assessment of leukocyte alterations at diagnosis of septic shock. Shock. 2010;34:358-63.

24. Shankar-Hari M, Fear $D$, Lavender $P$, et al. Activation-associated accelerated apoptosis of memory B cells in critically ill patients with sepsis. Crit Care Med. 2017:45:875-82.

25. Eriksson EM, Milush $\mathrm{JM}, \mathrm{Ho}$ EL, et al. Expansion of $\mathrm{CD}^{+} \mathrm{T}$ cells lacking Sema4D/CD100 during HIV-1 infection identifies a subset of T cells with decreased functional capacity. Blood. 2012;119:745-55.

26. Li BJ, He Y, Zhang Y, et al. Interferon-a-induced CD100 on naïve CD8 ${ }^{+} \mathrm{T}$ cells enhances antiviral responses to hepatitis C infection through CD72 signal transduction. J Int Med Res. 2017:45:89-100. 
27. Deaglio S, Vaisitti T, Bergui L, et al. CD38 and CD100 lead a network of surface receptors relaying positive signals for B-CLL growth and survival. Blood. 2005; 105:3042-50.

28. Granziero L, Circosta P, Scielzo C, et al. CD100/Plexin-B1 interactions sustain proliferation and survival of normal and leukemic $\mathrm{CD}^{+} \mathrm{B}$ lymphocytes. Blood. 2003;101:1962-9.

29. Inoue S, Suzuki K, Komori Y, et al. Persistent inflammation and T cell exhaustion in severe sepsis in the elderly. Crit Care. 2014;18:R130.

30. Suzuki K, Inoue S, Kametani Y, et al. Reduced Immunocompetent B Cells and Increased Secondary Infection in Elderly Patients with Severe Sepsis. Shock. 2016:46:270-8.

31. Boes M, Prodeus AP, Schmidt T, et al. A critical role of natural immunoglobulin $M$ in immediate defense against systemic bacterial infection. J Exp Med. 1998;188:2381-6.

32. Márquez-Velasco R, Massó F, Hernández-Pando R, et al. LPS pretreatment by the oral route protects against sepsis induced by cecal ligation and puncture. Regulation of proinflammatory response and IgM anti-LPS antibody production as associated mechanisms. Inflamm Res. 2007;56:385-90.

33. Shi W, Kumanogoh A, Watanabe C, et al. The class IV semaphorin CD100 plays nonredundant roles in the immune system: defective $B$ and $T$ cell activation in CD100-deficient mice. Immunity. 2000;13:633-42.

34. Boomer JS, Green JM, Hotchkiss RS. The changing immune system in sepsis: is individualized immuno-modulatory therapy the answer? Virulence. 2014;5: 45-56.

35. Hardy RR, Hayakawa K. B cell development pathways. Annu Rev Immunol. 2001;19:595-621.

36. Pan C, Baumgarth N, Parnes JR. CD72-deficient mice reveal nonredundant roles of CD72 in B cell development and activation. Immunity. 1999;11:495506

37. Duan $\mathrm{S}$, Jiao $\mathrm{Y}$, Wang J, et al. Impaired B-cell maturation contributes to reduced B cell numbers and poor prognosis in Sepsis. Shock. 2020;54(1):70-7.

\section{Publisher's Note}

Springer Nature remains neutral with regard to jurisdictional claims in published maps and institutional affiliations.

Ready to submit your research? Choose BMC and benefit from:

- fast, convenient online submission

- thorough peer review by experienced researchers in your field

- rapid publication on acceptance

- support for research data, including large and complex data types

- gold Open Access which fosters wider collaboration and increased citations

- maximum visibility for your research: over $100 \mathrm{M}$ website views per year

At $\mathrm{BMC}$, research is always in progress.

Learn more biomedcentral.com/submissions 